УДК 355.233.231.1+374.32

DOI: $10.32340 / 2514-772 X-2021-1-47-50$

\author{
В. В. Медведенко, \\ кандидат педагогических наук \\ Алтайский государственный институт культуры (Барнаул, Россия) \\ medvedenko-vera@mail.ru
}

\title{
СОХРАНЕНИЕ И ПОПУЛЯРИЗАЦИЯ ИСТОРИЧЕСКОГО НАСЛЕДИЯ НА ОСНОВЕ ОРГАНИЗАЦИИ СЦОЦИАЛЬНО-КУЛЬТУРНОГО ПРОЕКТА «ИСТОРИЯ В ЛИЦАХ»
}

Аннотация. В статье рассматривается социально-культурная технология - квест для школьников и молодежи в процессе реализации для сохранения и организации социальнокультурного проекта. Рассматривается механизм реализации квестов. Определены предполагаемые педагогические результаты применения данной технологии на практике.

Ключевые слова: социально-культурный проект, сочиально-культурные технологии, формы сочиально-культурной деятельности, квест, сохранение и популяризация исторического наследия.

Сохранение и популяризация историкокультурного наследия - это проблема, которая приобрела сегодня наибольшую актуальность. Человечество критически взвешивает доставшееся ему наследство в каждую историческую эпоху, дополняет, развивает и обогащает его в свете новых возможностей и новых задач, стоящих перед обществом. Поэтому сохранение исторического наследия это не просто сохранение народной памяти, но и формирование ценностей, формирование нового пространства, мышления, опираясь на опыт прошлого. Э. А. Баллер определяет культурное наследие как «совокупность связей, отношений и результатов материального и духовного производства прошлых исторических эпох, а в более узком смысле слова - как совокупность доставшихся человечеству от прошлых эпох культурных ценностей, критически осваиваемых, развиваемых и используемых в соответствии с объективными критериями общественного прогресса» $[1$, c. 56].

Мероприятия, которые начались в нашей стране с 2014 г., объявленного в России Годом культуры, направлены были на воспитание чувства национального самосознания и национальной гордости. Итогом данного года стал Указ Президента от 24.12.2014 г. № 808 «Основы государственной культурной политики» [2]. Основной целью данного документа провозглашено формирование гармонично развитой личности и укрепление единства российского общества посредством приоритетного культурного и гуманитарного развития. Целями культурной политики являются: укрепление гражданской идентичности; создание условий для воспита- ния граждан; сохранение исторического и культурного наследия и его использование для воспитания и образования [3].

В работе с молодыми людьми важно, наряду с традиционными, применять новые формы социально-культурной работы, используя новейшие разработки и технологии, потенциал художественных методов. В настоящее время существуют уже сложившиеся ставшие традиционными, проверенные временем формы социально-культурной работы с представителями молодого поколения, такие как театрализованные праздники, фестивали, выставки, творческие встречи, концертные программы, хэппиненги, перформансы, челленджи, квизы, квесты и др. При этом эти формы существуют и как форма социально-культурной деятельности, и как педагогическая технология.

Квест-технология - это педагогическая технология, основанная на системнодеятельностном и личностном подходах, сочетающая технологии проблемного, проектного и игрового обучения, с целью достижения определенных целей и ориентированная на формирование познавательной активности и мотивации участников, развитие их, как активных участников педагогического процесса [5].

Рассматривая это понятие подробнее, мы для себя определяем, что «quest» по-английски означает «поиск», «искомый предмет». Созвучный глагол «to quest» переводится как «искать», «разыскивать» [6].

Выражаясь простыми словами, квест - это движение к определенной цели, связанное с преодолением трудностей и поиском чего-либо. Наглядно представить это можно, вспомнив 
телепередачу «Форт Боярд». Элементами квеста насыщен фольклор (12 подвигов Геракла, сказка о Кощее, смерть которого в игле, игла в яйце, яйцо в утке, и т. д.).

Постепенно это понятие стало использоваться в других сферах, изменив первоначальный смысл. Но чаще всего оно используется в игровой индустрии.

«Квест - это интеллектуальный вид игровых развлечений, во время которых участникам предстоит преодолеть ряд препятствий, решить определенные задачи, разгадать логические загадки, справится с трудностями, возникающими на их пути, для достижения общей цели» [4]. Квест позволяет стимулировать интерес к историческому наследию, показывает необходимость его практического применения. Наша история - это то, что выделяет нас, делает особенными. Не зная ничего про свою малую родину, человек просто теряется в толпе, лишается своей индивидуальности. Современная молодежь часто не готова быть вовлеченной в предлагаемые мероприятия, направленные на изучение истории малой родины. Так как форма организации подобных мероприятий носит часто поучительный, назидательный характер информация не усваивается. Поэтому исторические квесты для молодежи - это популярная и необходимая форма и технология в наше время.

Впервые термин «квест» в качестве образовательной технологии был предложен летом 1995 года Берни Доджем, профессором образовательных технологий Университета Сан-Диего. Ученый разрабатывал инновационные приложения Internet для интеграции в учебный процесс при преподавании различных учебных предметов на разных уровнях обучения. Квестом он назвал сайт, содержащий проблемное задание и предполагающий самостоятельный поиск информации в сети Интернет. Берни Додж выделяет три принципа классификации веб-квестов: 1. По длительности выполнения. 2. По предметному содержанию. 3. По типу заданий, выполняемых участниками [4].

Берни Додж по длительности выполнения различают два типа веб-квестов: кратковременный (цель: углубление знаний и их интеграция, рассчитаны на 1-3 встречи); длительный (цель: углубление и преобразование знаний учащихся, рассчитаны на длительный срок).

Время проведения варьируется от получаса до нескольких месяцев. Целью кратковременных квестов считается получение знаний и добавление их в свою копилку знаний. Долгосрочные квесты предполагают расширение и уточнение понятий. После прохождения долгосрочного квеста, участник должен уметь анализировать обретенные знания, быть способен их преобразовывать.

Исследователь Том Марч определил следующие требования к организационным особенностям: замотивированность участников; безопасность (это может быть экстремальность, в идеале, выражена в нелинейности сюжета, ограниченное время, необходимости действовать быстро и решительно). В исключительных случаях, когда 24 условия проведения квеста действительно экстремальные (горы, лес, заброшенные здания), дополнительно понадобится контроль и компетентная подстраховка, а также участники должны предварительно пройти специальную подготовку); - многообразие заданий; - оригинальность; - спонтанность развития событий; - логичность; - целостность; подчинённость поставленным дидактическим задачам [5].

Квест как форма и технология, позволяет участникам быть активными участниками действия, творчески взаимодействовать друг с другом, быстро принимать решения и навыки работы в команде. Преподаватели и студенты кафедры социально-культурной деятельности разработали социально-культурный проект «История в лицах». Большой опыт работы руководителей проекта в сфере социально-культурной деятельности позволил разработать проект по сохранению культурного наследия в познавательной и развлекательной форме. Данный проект нацелен на людей молодого возраста в целом и школьников, студенческую молодежь, семейную молодежь в частности. Проект направлен на обеспечение максимальной вовлеченности молодых людей в социальнокультурную деятельность с применением художественных методов, форм и технологий для изучения и сохранения истории родного города, а также в качестве инструмента оптимизации патриотических и гражданских ценностей. Сам процесс приносит удовольствие, обучает выражать свои переживания как можно более спонтанно и произвольно. Отличительной особенностью использования художественных технологий является их интегративный характер, позволяющий наряду с традиционными формами, использовать еще и перформанс, хэппиненги, челленджи, квизы, квесты.

Квест-игра направлена на сохранение истории города и исторических персоналий, создававших историю города и развивавших его. Основной идеей проекта является обеспечение 
вовлеченности молодых людей - учащихся старших классов, студентов вузов, молодых семей в социально-культурную деятельность города с помощью организации 3 квестов-игр: «Барнаул - столица мира», «Барнаул - маленький Петербург», «Серебряный край Демидова».

Численность людей (молодежь от 14 до 30 лет), вовлеченных в проект более 650 человек (исполнители более 250 человек), благополучатели (около 400 человек). Исполнители проекта стали преподаватели и студенты Алтайского государственного института культуры, сотрудники культурно-досуговых учреждений города (музеев, выставочных залов, театров). Проект предположительно стартует с сентября 2021 года.

К целям проекта относятся: 1. Сохранение и популяризация исторического наследия на основе организации квест-игры и создания своей творческой продукции (челленжей, видеороликов, видеотчетов и т. п.); воспитание чувства гордости за историческое и культурное наследие своего народа; пробуждение интереса и уважения к истории города, любви к родному краю. 2. Культурное обслуживание. 3. Повышение интереса населения Алтайского края к экспозициям культурных учреждений города и края.

В процессе разработки проекта были определены следующие задачи:

Задачи первого этапа:

1. Изучение истории города интересов и запросов молодежи.

2. Организация квест-игры с использованием театрализации и празднично-игровых технологий на исторически значимых площадках города силами преподавателей и студентов АГИК.

Задачи второго этапа:

3. Помощь волонтеров в оформлении исторически значимых площадок (этапов маршрута) в ходе подготовки к квесту-игре.

4. Обучение группы студентов-кураторов и студентов-аниматоров и репетиции творческих эпизодов - на этапах, вовлекающих в процесс подготовки квеста; активизация стремления к созданию молодежью своей творческой продукции.

5. Проведение аниматорами театрализованных эпизодов на этапах квеста-игры из истории города.

6. Организация различных форм демонстрации полученных в ходе программы результатов: видеозарисовки, фотоотчеты, роликов, челленджей в соцсетях.

Задачи третьего этапа:
7. Применение метода интервьюирования, для того, чтобы высветить положительные моменты проведения квеста-игры

8. Создание рекламного буклета по использованию форм, технологий, художественных методов

Основные исполнители проекта - студенты и преподаватели АГИК, сотрудники учреждений культуры (музеев, кинотеатра «Премьера», выставочных залов) оказывают помощь в реализации проекта (готовят площадку, информируют о предстоящих событиях и т. п.).

В медиаплан проекта входит презентация программы (государственное телевидение и радио «Алтай» (ГТРК), телеканал «Катунь-24», телеканал «Толк»); освещение работы этапов площадок; работа волонтерских отрядов и аниматоров по подготовке квеста-игры; презентация проекта.

Таким образом, к планируемым результатам проекта можно отнести: пробуждение интереса молодежи к историческому наследию города; повышение знаний о родном городе и людях, создававших историю; укрепление семейных ценностей в молодых семьях; создание опыта внедрения инновационных социальнокультурных форм при работе с историей города и сохранением исторического наследия; создание методической базы сценариев квестов по истории города и края и внедрение их в работу культурно-досуговых учреждений города. В дальнейшем предполагается выпустить рекламный буклет по применению социальнокультурных технологий, форм, художественных методов при работе с молодежью.

\section{Список литературы}

1. Баллер Э.А. Социальный прогресс и культурное наследие. Москва, 1987. 160 с.

2. Данилюк А. Я., Кондаков А. М., Тишков $B$. A. Концепция духовно-нравственного развития и воспитания личности гражданина России. Москва, 2009. 26 с.

3. Кругликова Г. А. Сохранение культурного наследия как фактор социального здоровья нации. URL: https://art-oleg.blogspot.com/ 2015/05/blog-post.html (23.02.2021).

4. Квест-технология в ДОО. URL: https://opdo-fgosdo.ru_(23.02.2021).

5. Игумнова Е. А., Радец̧кая И. В. Квесттехнология в образовании. Чита, 2016. 164 с.

6. Что такое квест. URL:

https://ktonanovenkogo.ru/voprosy-i -otvety/kvestchto-ehto-takoe.html (23.02.2021). 